\title{
The landscape of diabetic foot in Peru.
}

\author{
Ericka Saravia-Hernánde: ${ }^{1}$, José Salvador-Carrillo ${ }^{2,3}$, Alejandra Zevallos ${ }^{1}$ \\ and Jorge Calderón-Ticona ${ }^{4,5}$
}

${ }^{1}$ Escuela Profesional de Medicina Humana, Universidad Privada San Juan Bautista, Chorrillos, Lima, Perú.

2 Escuela Profesional de Medicina Humana, Universidad Privada San Juan Bautista, Chincha Alta, Ica Perú.

${ }^{3}$ Universidad Privada San Juan Bautista, Av. José Antonio Lavalle, Chorrillos, Lima, Perú.

${ }^{4}$ Hospital Nacional Arzobispo Loayza, Lima, Perú.

5 Facultad de Medicina "San Fernando", Universidad Nacional Mayor de San Marcos, Cercado de Lima, Lima, Perú.

Key words: diabetic foot; diabetes mellitus; Peru; Public Health.

Abstract. Diabetic foot (DF) is one of the main complications responsible for the significant deterioration of the quality of life in diabetic patients, particularly, in developing countries. In Peru, 18.9\% of diabetic inpatients present DF and 61\% develop a foot sepsis. Therefore, the burden of DF is considerable in the country. In this work, we summarize the current scientific evidence of DF in the Peruvian population describing its epidemiology, risk factors, increase of time of hospitalization, bacterial resistance, rate of amputations, and the theoretical medical costs for disease management. According to the reviewed literature, we suggest that more local research should be conducted to better understand the impact of the DF on the Peruvian population.

Corresponding author: Karla Alejandra Vizcarra Zevallos. Escuela Profesional de Medicina Humana, Universidad Privada San Juan Bautista, Chorrillos, Lima, Perú. Telephone: 051926546720. Email: karla.vizearra@upsjb.edu.pe 


\section{El panorama del pie diabético en el Perú.}

Invest Clin 2021; 62 (3): 276-289

Palabras clave: pie diabético; diabetes mellitus; Perú; Salud Pública.

Resumen. El pie diabético (PD) es una de las principales complicaciones responsables del deterioro de la calidad de vida de los pacientes diabéticos, particularmente en países en vías de desarrollo. En Perú, el 18,9\% de los pacientes diabéticos hospitalizados presentan PD y el 61\% desarrolla una sepsis del pie. Por lo tanto, la carga de PD es considerable en el país. En el presente trabajo, se ha resumido la actual evidencia científica sobre el PD en la población peruana de esta manera, describiendo su epidemiología, factores de riesgo, incremento en el tiempo de hospitalización, resistencia bacteriana, tasa de amputación y el costo médico teórico del manejo de esta patología. De acuerdo con nuestra revisión de la literatura, se considera que más estudios locales deben ser conducidos para mejorar el entendimiento del impacto del PD en la población peruana.

Received: 28-12-2020Ａccepted: 04-05-2021

\section{INTRODUCTION}

Diabetes mellitus (DM) burden represents a serious problem for public health in Latin America. In fact, it is expected that it will affect up to 49.1 million people by 2045 (1). Diabetic Foot (DF) disease is considered as one of the principal complications of DM and it usually has a multifactorial origin. Among its principal contributors are peripheral neuropathy and vascular disease, which can be found in $10 \%$ of diabetic type 2 patients and can lead to foot ulceration $(2,3)$. The lifetime risk of developing at least one diabetic foot ulcer is between 15 to $25 \%$ (4).

In general, this pathology is characterized by ulceration, infection or destruction of foot tissue (5). More than half of diabetic foot infections lead to foot ulcers, which usually ends in lower extremity amputation (6). Other complications that are often present coupled with DF are nephropathy, retinopathy, ischemic heart disease and cerebrovascular disease $(7,8)$. DF is attributed for increasing hospitalization time, amputation rates, costs for the health system and deterioration of the patient's quality of life (4,9-11).

To date, DF prevalence in DM patients who were hospitalized is $18.9 \%$, representing an important disease burden in Perú (12). Therefore, this work aims to present a review of the scientific data published about DF in order to improve the understanding of the epidemiology, clinical characteristics and the economic impact of this pathology in the country.

In order to limit our research, we looked for papers in SCOPUS, PubMed, SciELO, LILACS and Google Scholar databases from January 1 to October 30, 2020. The keywords used for the search were "diabetic foot" AND "diabetic foot ulcer" AND "diabetes" AND "Peru" AND "epidemiology". For the Spanish database, equivalents keywords were used according to the Health Sciences Descriptors (DECS). Reference lists of all the included papers were reviewed to identify potential papers.

Papers written in Spanish, Portuguese or English were considered and studies involving the Peruvian population were included. We did not restrict the study's design

Vol. 62(3): 276 - 289, 2021 
(population-based, medical records review, clinical-based, others) or the level (national or regional) of the studies. Two investigators reviewed the titles and abstracts of papers independently. Relevant articles were selected, and disagreements were discussed and solved by the senior investigator.

\section{DIABETIC FOOT EPIDEMIOLOGY IN PERU}

According to the World Health Organization (WHO) DF is an infectious process which leads to the destruction of deep tissue of the feet, associated with neurological abnormalities, such as loss of sensitivity to pain, and peripheral vascular disease of varying severity in the lower limbs (13).

In Latin America, a cross-sectional and multicentric study (from nine countries, including Peru) found that the rate of DF in 11,357 inpatients (mean age 61.7 years) was 14.8\% (CI 95\%; 14.1-15.4) (14). In Perú, Yovera-Aldana et al. (12) reported that the prevalence of DF inpatients was 2.8\% (95\% CI: 2.4-3.1) and the prevalence among DM inpatients was 18.9\% (CI 95\% 16.7-21.1). In this study, 8,346 patients from 39 health centers were included (age $62 \pm 12$ years). On the other hand, Ramos et al. (15) described that the rate of DF was $6 \%$ in DM patients (including inpatients and outpatients), leading as the second most frequent complication in this population. This study included 2,959 diabetic patients (57.2 \pm 15.7 years) from 18 hospitals that belonged to the diabetes surveillance system of Peru during 2012.

Additionally, Lazo-Porras et al. (16) showed an 18-month incidence in diabetic patients at risk of foot ulcers (risk groups 2 or 3 according to the International Working Group on the Diabetic Foot (IWGDF)). DF ulcers cumulative incidence was $17.7 \%$ $(28 / 158)$ in the total sample (mean age 61 years); however, it was higher among patients with a history of previous ulceration $(27.8 \%, 25 / 90)$.
In literature, these papers were the only ones that described the prevalence and incidence of DF among Peruvian diabetic patients; nevertheless, more studies should be conducted to improve the understanding of the epidemiological situation of DF in vulnerable populations $(17,18)$.

DF represents one of the main causes of hospitalization due to infections in diabetic patients, especially in elderly patients with long standing illness (19). It is estimated that DF is the cause of approximately 50\% of diabetes-related hospital admissions (20). In a study made in Peru, from an analysis of 1,230 admissions of diabetic patients in a tertiary care public hospital, it was found that DF was the most common cause of hospitalization, which accounted for up to $20.5 \%$ of the total analyzed samples (21). Similarly, Gonzales-Grández et al (22) found that DF infection was the second leading cause of hospitalization (20.8\%) in 424 diabetic patients (40.6\% over 65 years). These results are lower than those reported in other countries $(20,23,24)$, but similar to other studies carried out in South America such as Brazil, where complications related to DF were the cause of $18.2 \%$ of all hospital admissions in diabetic patients (25).

The DF patient's quality of life is deeply affected across familial, economic, and social levels $(25,26)$. Amputation by DF not only causes disability, functional impairment or consequential dependence on relatives (27), but it also leads the patient to develop emotional disorders such as depression (28).

\section{RISK FACTORS ASSOCIATED WITH DIABETIC FOOT}

Risk factors play an important role in the pathology of DF since they are related to its evolution and complications. In Peru, risk factors has been described in some studies such as peripheral neuropathy (PN), peripheral vascular disease (PVD), disease time, inadequate glucose control, comorbidities, among others $(26,27)$. The most frequent 
factors associated with DF in the Peruvian population are described below:

\section{Peripheral Neuropathy}

This pathology is one of the main complications of DM and is one of the most common risk factors for the development of DF. It can be found in up to $69 \%$ of diabetic patients and it is directly associated with the long-standing DM (28). In Perú, the frequency of PN among patients with DF can depend on some factors, such as time of disease and type of patient care (outpatient vs inpatient). Torres-Aparcana et al. (27) found that PN was present in $95 \%$ of all the hospitalized diabetic patients in a tertiary care public hospital $(\mathrm{n}=166 ; 59.4 \pm 12.0$ years $)$. The average time of disease was $12.5 \pm 8.1$. On the other hand, Damas-Casani et al (29) found that just $35 \%$ of total ambulatory patients $(n=370 ; 60.3 \pm 11.1$ years $)$ presented PN. In this study, $60 \%$ of patients had more than 5 years since the diagnosis of the disease. Additionally, PN was defined differently in both studies.

A case-control study carried out by Arribasplata and Lena-Muñoz (26) showed a significant association between DF with PN (OR: 2.88, 95\% CI: 1,45-5,72) in univariate analysis. However, this association was not observed in multivariate analysis $(\mathrm{p}>0.05)$. The sample $(n=165)$ comprised patients treated at the Endocrinology Service in a tertiary care public hospital. PN was present in $69 \%$ of them. Furthermore, $70.3 \%$ of patients were older than 60 years and $70.9 \%$ of the subjects had a diabetes diagnosis of over 10 years. The criteria to identify peripheral neuropathy was not disclosed by the authors.

\section{Peripheral vascular disease}

Patients with DM have a high risk of developing PVD. This complication alone can rarely cause ulceration, but when PVD is present with NP and a minor trauma, this can lead to tissue breakdown (30) and critical complications such lower limb amputation $(31,32)$. Torres-Aparcana et al (27) also described the frequency of PVD in their retrospective crosssectional study. This pathology was present in $51.2 \%$ of all the patients $(n=166 ; 59.4 \pm 12.0$ years). In addition, PN was the most frequent co-morbidity in patients with PVD (88.2\%). Damas-Casani et al (29) found that PVD was present in $38 \%$ of the total patients $(n=370$; $60.3 \pm 11.1$ years) who were treated at the Diabetic Foot Unit of a tertiary care public hospital. These different outcomes may be explained through patient's characteristics as well previously commented in the PN section (time of disease and type of patient care). These differences were consistent with another study that evaluated 301 diabetic patients attended in a tertiary care public hospital in the city of Trujillo, a northern Peruvian city. PVD was present in $18.6 \%$ of all the patients, but it was present in $89 \%$ of the patients who were over 50 years old, and $61.5 \%$, with a time from diagnosis higher than 5 years (33).

In the study of Arribasplata and LenaMuñoz (26), PVD was reported in $56.4 \%$ of DF patients and a significant association was found between those two variables (OR $=2.54 ; 95 \% \mathrm{CI}=1.31-4.94)$ in univariate analysis. Nevertheless, similarly to PN, this association was not observed in multivariate analysis. For a more detailed information about population baseline characteristics, the PN section summarized this data.

\section{Time of disease from diagnosis}

The time of disease is a critical factor associated with DF degree of severity. TorresAparcana et al (27) found that the average time from the diagnosis of diabetes to the appearance of the first lesion in the foot was $12.5 \pm 8.1$ years in hospitalized patients $(\mathrm{n}=166 ; 59.4 \pm 12.0$ years). Studies carried out in developing countries reported similar data $(24,34,35)$; however, in developed countries, the time to the first lesion is higher $(19,36,37)$. As a matter of fact, DF time to disease is delayed in developed countries due to higher education levels and broader access to adequate treatment and health care services (38). 
In Latin America, a multicenter study executed in 1,677 hospitalized patients who had DF (14), reported a median time of disease of 10 years. Furthermore, it found that patients with lesions 0 and 1 , according to the Wagner scale, had shorter time from diagnosis when compared to patients with Wagner lesions $\geq 2(\mathrm{p}<0.001)$. Seven Peruvian public hospitals of 135 Latin America health centers contributed towards this study (14). The population average age was 61.7 years.

Additionally, in the work by Arribasplata-Espinoza and Luna-Muñoz (26), multivariable analysis evidenced that people with a time of disease greater than 10 years had a higher risk for developing DF in this study (OR: 12.77, 95\% CI: 4.12 - 39.60).

Inadequate glucose control

Poor long-term glucose control is critical for the development of diabetic foot ulceration and other complications $(35,36)$. Although this fact is important for the management and prevention of DF in diabetic patients, developing countries do not usually have a health care system that ensures adequate glucose control in their population (38).

In Peru, a study carried out in 18 Peruvians hospitals with 2,959 patients evaluated glycated hemoglobin (HbA1c) and fasting glycemia levels at two time points: at the time of enrollment and the last follow-up visit. The outcomes showed that $73.4 \%$ of all patients had levels $\geq 7.0 \%$ HbA1c while $63.5 \%$ had values $\geq 130 \mathrm{mg} / \mathrm{dL}$ of glycemia. The average time from diagnosis in this population was 5.6 years, and the average age was $\mathbf{5 7 . 2}$ \pm 15.7 years old (15). Furthermore, this work showed the rate of treatment abandonment in Peruvian diabetic patients (65.3\%) and the high frequency of inadequate glucose control within them.

Inadequate glucose control in diabetic patients has also been associated with DF. In the study of Arribasplata and Lena-Muñoz (26) it was found that patients with poor
HbA1c management presented a risk of 6.2 times higher for DF development $(95 \% \mathrm{CI}=$ 1.79-21.41) in multivariate analysis.

\section{Comorbidities}

The presence of other comorbidities leads to an increased risk for the development of DF. Nevertheless, only one work considered them in its analysis in Peruvian medical literature. In this case-control study, chronic kidney disease, obesity, arterial hypertension, dyslipidemia, and onychomycosis were present in $36.4 \%, 85.5 \%$, $67.3 \%, 49.1 \%$ and $94.5 \%$ of total samples (case group: 55 DF patients), respectively. However, only chronic kidney disease (OR: 3.023, CI 95\%: 1.014- 9.013) and onychomycosis (OR: 7.1; CI 95\%: 1.5-34.1) increased the risk for DF in logistic regression analysis. Obesity and arterial hypertension were significant in univariate analysis but not in multivariate analysis. On the other hand, dyslipidemia behaved as a protective factor (OR: 0.24; CI 95\% $0.11-0.48)(26)$. The apparent contradiction of these outcomes with the international literature $(35,36,39)$ may probably be explained by the size of the samples. In accordance with this, some variables had a wide CI 95\%. In this study, more than 70\% of total patients were older than 60 years old and had a diabetes diagnosis of over 10 years.

\section{Age of patients}

The age of patients is also an important factor in the development of DF. A crosssectional study that reviewed the medical records of 166 patients hospitalized due to DF in a tertiary care public hospital found that $60.8 \%$ of the individuals were aged between 50 and 69 years old (27). Moreover, Arribasplata and Lena Muñoz (26) found that 70.3\% of DM patients $(n=165)$ with DF were older than 60 years. However, an age over 60 years was not significantly associated with the development of DF $(p=0.22)$. 


\section{PROLONGED LENGTH OF STAY IN HOSPITAL}

DF is usually the main reason for the admission of diabetic patients in hospitals and it has a significant socioeconomical impact in the health care system budget (40). Hospital length-of-stay tends to be longer in diabetic patients with DF. According to the National Diabetes Foot Care Audit (NDFA) Hospital Admissions Report 2014-2017 (41), more than 95,000 hospital bed-days were occupied by DF patients, and median hospital length-of-stay for major amputation was 25 days. Another report showed that the lengthof-stay for inpatients with DF is longer than those without diabetes (median stay: 8 nights vs 5 nights, respectively) and it represented 5,912,837 bed-days per year (4).

In Latin America, a multicenter study made with 11,357 DF patients from 135 health centers (seven health centers from Peru reported that the median length of hospital stay was 10 days (14). In Peru, a longitudinal observational study found that DF patients $(n=424)$ spend longer periods of time hospitalized among the diabetic inpatients (average of 21.2 days and a maximum stay of 90 days). In this population, the median age and time from diagnosis was 64 and 9.5 years, respectively. Furthermore, more than half of the patients had some diabetes complication. These risk factors were probably the reason for the higher length of hospitalization in this study (22).

Similar outcomes were found in a retrospective study in three tertiary care public hospitals in Cusco, a southern region of Peru. The median of hospital days of diabetic patients with DF (20 days, interquartile range (IQR): 14 - 31 days) was higher in comparison to those without DF diagnosis (9 days, IQR: 5 - 14 days). An increase in the number of hospitalization days (17 days more, 95\% CI $=5.7-28.3$ days, $\mathrm{p}=0.003$ ) was attributed to DF. The median age and time from diagnosis of this population $(n=153)$ were 61 and 13 years, respectively (42).

On the other hand, Torres-Aparcana et al (27) found different hospital lengthof-stays among 166 patients with DF attended in other public hospitals. Patients who received only medical treatment presented an average hospital length-of-stay of $13.32 \pm 12.0$ days, which was considerably lower than those who underwent some type of surgical treatment [32 \pm 13.4 days $(\mathrm{p}<0.001)]$. In this population, the average age and time of disease was $59.4 \pm 12$ years and $12.5 \pm 8.1$ years, respectively. The increase of hospital length-of-stay in an operatively treated DF patient in comparison with a non-operatively treated $\mathrm{DF}$ patient was consistent with other studies $(43,44)$.

\section{BACTERIAL RESISTANCE IN PATIENTS WITH DLABETIC FOOT}

Infections are one of the main causes of hospitalizations, amputations, and death in patients with DM in Peru, and DF is one of the most frequent types of infections $(22,45-47)$. When a patient with infected DF is attended, they are first empirically treated a then sampled in order to provide a personalized treatment based on culture and antibiogram results. However, the decision-making process might become complex according to bacterial resistance and the population-based clinical evidence available, as well as the severity of the infection, previously prescribed antibiotics, and stock availability in the hospital (48).

A retrospective and descriptive work carried out at a third-level public hospital evaluated the infection of DF in 95 patients (average age $61.7 \pm 11.6$ years and time from diagnosis $10.75 \pm 7.9$ years). In this work, 109 infection events were identified, and 132 bacteria strains were isolated. Gram $(+)$ bacteria were isolated in 73 cases $(55 \%)$, in which Staphylococcus aureus was the

Vol. 62(3): 276 - 289, 2021 
most frequent (48\%). Among the remaining cases, the most frequent Gram (-) bacteria were Escherichia coli (49\%). When susceptibility to antibiotics was analyzed, $S$. aureus was sensitive to clindamycin, oxacillin, and vancomycin in $25 \%, 32 \%$, and $100 \%$ of the cases, respectively. Imipenem was $100 \%$ effective against bacteria from the genus $\mathrm{En}$ terobacteriaceae and Pseudomonas aeruginosa. On the other hand, $0 \%$ sensitivity was found for some antibiotics in the case of $P$. aeruginosa against ceftriaxone and aztreonam, and Enterococcus spp. for elindamycin and oxacillin. Patients with DF who belong to risk groups 1 to 3 , according to the Wagner scale, had an increased risk of being infected with Gram (+) bacteria rather than with Gram (-) $(\mathrm{OR}=3.11$, 95\% CI: 1.2-7.8). In addition, patients with DF which presents neuropathy or vascular diseases concomitantly, had a higher risk of infection by Gram $(+)$ germs with resistance to oxacillin (OR $=8.2,95 \% \mathrm{CI}=1.5-43.5$ and $\mathrm{OR}=6.3,95 \%$ $\mathrm{CI}=1.2-32.4$, respectively) (49).

Another cross-sectional study evaluated bacterial resistance and associated factors in 88 patients with infected DF with no major amputation outcomes, attended at a thirdlevel public hospital. The average age of the patients was $60.6 \pm 12$ years with a median time from diagnosis of 15 years. Among them, patients classified as grades 3 and 4 in the Wagner scale were the most frequent (39.8\% and 40\%, respectively). Polymicrobial cultures represented $42 \%$ of the total and the most frequently isolated bacteria were Escherichia coli (23.4\%), Enterococcus faecalis (14.1\%) and Staphylococcus aureus (13.3\%). In terms of antibiotic resistance, 33\% of Enterobacteriaceae were beta-lactam resistant and Extended-Spectrum Beta-lactamases (ESBL) producers. On the other hand, Gram (-) bacteria such as $P$. aeruginosa and $A$. baumanii were highly resistant to carbapenem agents (83\% and 100\%, respectively). Interestingly, no cases of vancomycin resistance in $S$. aureus or E. faecalis were reported. The presence of ESBL positive bacteria was as- sociated with a previous DF infection, high levels of C-reactive protein (PCR) and scores in the Laboratory Risk Indicator Necrotizing fasciitis (LRINEC) higher than 6, when compared to patients carrying ESBL negative bacteria $(\mathrm{p}<0.05)$. The presence of positive methicillin-resistant $S$. aureus (MRSA) was only associated with high CRP values in diabetic patients $(\mathrm{p}<0.05)(46)$.

Another third cross-sectional study reviewed the medical records of 5007 patients with infected DF, and the aerobic cultures data was treated in the Diabetic Foot Program of a Peruvian public hospital (average age $60.7 \pm 12.2$ years, but time from diagnosis was not detailed). A total of $652 \mathrm{mi}-$ croorganisms were isolated: 407 Gram (-) and 245 Gram $(+)$ bacteria were identified. There were reported microorganisms with more than $90 \%$ of antibiotic sensitivity to vancomycin, teicoplanin, meropenem, and ertapenem. On the other hand, microorganisms were also found with more than $80 \%$ of antibiotic resistance to cotrimoxazole, amoxicillin, dicloxacillin, oxacillin, penicillin, cephalexin, and amoxicillin/clavulanic acid. Unlike the two aforementioned studies $(46,49)$, this work did not conduct additional analysis (50).

These three studies $(46,49,50)$ were the only papers found in Medical Literature that describe bacterial resistance in the Peruvian population with DF. The bacterial resistance was different among population studies, possibly due to unequal patients' conditions, the severity of DF, previous infections, and presence of comorbidities. We grouped the microorganisms with total bacterial resistance to at least one antibiotic found in these works in a heat map (Fig. 1).

\section{AMPUTATION OF THE DIABETIC FOOT}

Amputation patients represent prolonged hospital length-of-stay, increased by high dependency/Intensive Care Unit, multiple readmissions and a critical cost of pa- 


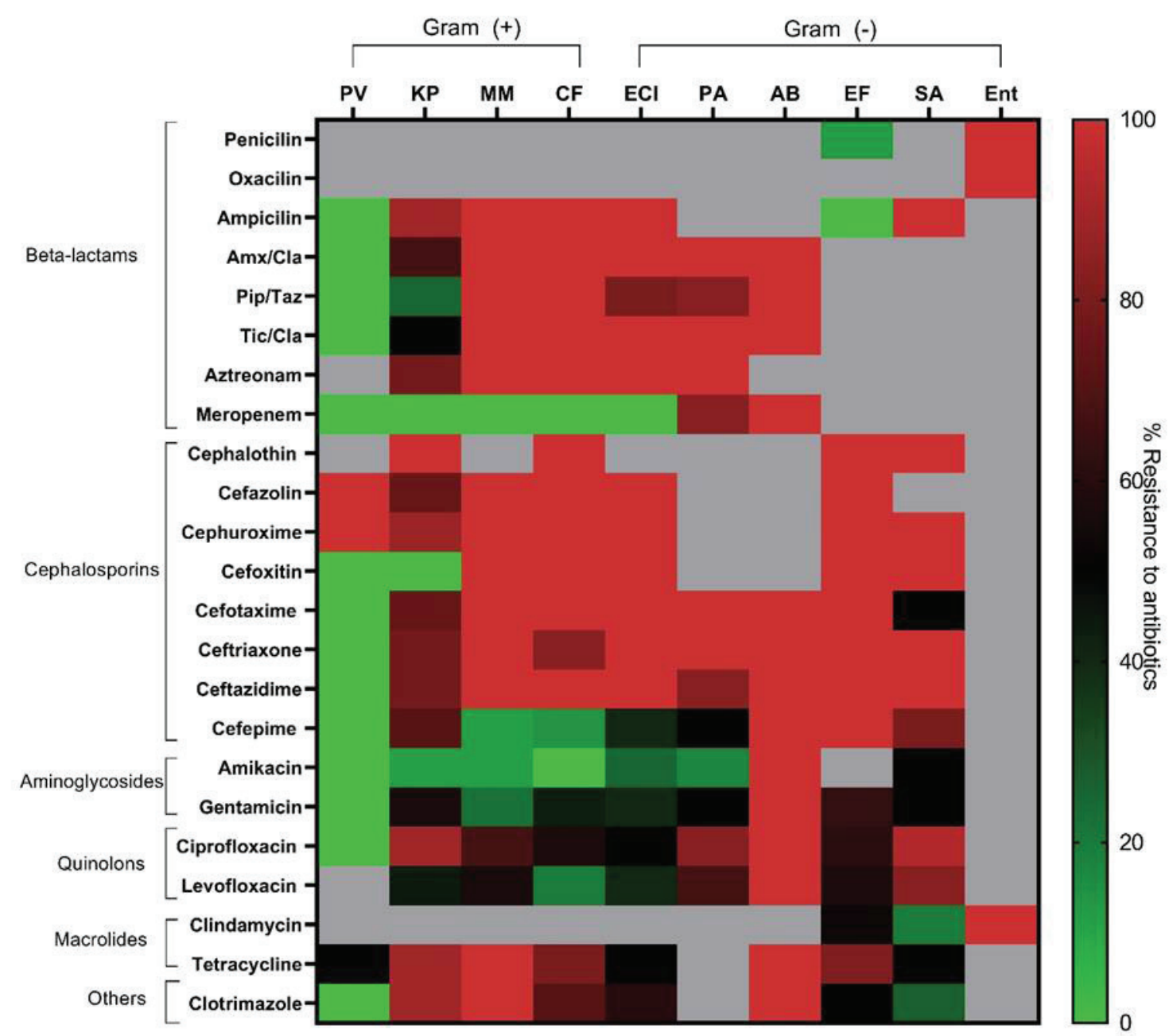

Fig. 1. Microorganisms with total bacterial resistance to at least one antibiotic found in patients with diabetic foot, attended at three hospitals of Peru. Microorganisms with 100\% bacterial resistance to at least one antibiotic found in Peruvian patients with infected DF attended at three hospitals $(46,49,50)$ were considered for this heatmap. Green to red gradient depicting resistance to antibiotics (0 to 100\%). No data for microorganisms/antibiotic matches is represented by grey background. Pip/Taz: piperacilin/tazobactam; Tic/Cla: ticarcilin/ clavulanic acid; PV: Proteus vulgaris; KP: Klebsiella pneumoniae; MM: Morganella morganii; CF: Citrobacter freundii; ECI: Enterobacter cloacae; PA: Pseudomonas aerugínosa; AB: Acinetobacter baumannii; EF: Enterococcus faecalis; SA: Staphylococcus aereus; Ent: Enterococo spp.

tients for public health (43). The lower-limb amputation in diabetic patients is eight times higher than in nondiabetic individuals (51) and approximately $85 \%$ of all amputations are preceded by DF ulceration (52). In addition, it is reported that every 30 seconds one leg is amputated due to DF ulceration worldwide (20).
In Perú, most of the limb amputations occurred in lower-limb amputation (78.1\%) and it is caused mainly by diabetic angiopathy (53). During the period 1989-1997, the frequency of amputation among DF patients was $61 \%(n=206$ DF inpatients, mean age was 61.4 years (range 27.-86)) (47). Interestingly, another study conducted at the 
same institution reported an increase of overall rate amputation to $64 \%$ in the period of 2006-2008 ( $n=166$ DF inpatients, mean age was $59.4 \pm 12.0$ years) (27). Despite that, the major amputation rate decreased between both periods (from $69.05 \%$ to $59.2 \%$ ). The reduction of the major amputation rate is probably due to an improvement in the early approach to DF patients, as well as the effect of multidisciplinary actions; however, more studies are necessary to confirm this hypothesis.

The cornerstone of DF patient care to reduce the amputation rate is the early identification of the risk factors associated with this endpoint in the population. Local knowl- edge of these factors and their influence on this outcome is critical for multidisciplinary teams to develop adequate management and treatment plans for their population (54); however, in Peru, few studies have been conducted to study these factors. Risks factors to amputation in Peruvian DF patients were summarized in Table I; however, these studies showed some limitations such as sample size $(55,56)$.

\section{COST OF DISEASE IN PATIENTS WITH DIABETIC FOOT}

As previously commented, DF-related complications represent a high human

TABLE I

RISK FACTORS ASSOCIATED WITH DIABETIC FOOT AMPUTATION IN THE PERUVIAN POPULATION.

\begin{tabular}{|c|c|c|c|c|c|}
\hline AUTHORS & POPULATION & $\begin{array}{c}\text { RISK } \\
\text { FACTORS FOR } \\
\text { AMPUTATION } \\
\end{array}$ & $\begin{array}{c}\text { TYPE } \\
\text { OF STUDY }\end{array}$ & FREQUENCY & $\begin{array}{c}\text { OR } \\
(95 \% \mathrm{CI})\end{array}$ \\
\hline \multirow[t]{4}{*}{$\begin{array}{l}\text { Nicho L. } \\
\text { et al (57) }\end{array}$} & \multirow[t]{4}{*}{218} & $\begin{array}{l}\text { Time from } \\
\text { diaǵnosis } \\
(>10 \text { years })\end{array}$ & Case-control & $88.10 \%$ & $3.21(1.58-6.51)$ \\
\hline & & Male gender & & $87.20 \%$ & $2.46(1.22-4.97)$ \\
\hline & & $\begin{array}{l}\text { Inadequate } \\
\text { glucose control } \\
(\geq 100 \mathrm{mg} / \mathrm{dL})\end{array}$ & & $52.30 \%$ & $3.68(2.06-6.60)$ \\
\hline & & $\begin{array}{l}\text { Wagner score of } \\
\text { lesion severity } \\
\text { (grade } 4 \text { ) }\end{array}$ & & $79.80 \%$ & $5.62(3.08-10.28)$ \\
\hline $\begin{array}{l}\text { Torres H. } \\
\text { et al (26) }\end{array}$ & 166 & $\begin{array}{l}\text { Peripheral } \\
\text { vascular disease }\end{array}$ & Cross-sectional & $84.70 \%$ & $6.59(3.03-14.33)$ \\
\hline \multirow[t]{3}{*}{$\begin{array}{l}\text { Vidal- } \\
\text { Domínguez } \\
(56)\end{array}$} & \multirow[t]{3}{*}{91} & $\begin{array}{l}\text { Time from } \\
\text { diagnosis } \\
\text { (> 10 years) }\end{array}$ & Case-control & $77.80 \%$ & - \\
\hline & & $\begin{array}{l}\text { Wagner score of } \\
\text { lesion severity } \\
\text { (grade } 4 \text { ) }\end{array}$ & & $77.80 \%$ & $7.79(3.12-20.53)$ \\
\hline & & $\begin{array}{l}\text { Absence of pulse } \\
\text { only in pedial and } \\
\text { posterior tibial } \\
\text { arteries }\end{array}$ & & $73.3 \%$ & $7.79(3.07-19.80)$ \\
\hline
\end{tabular}


and financial cost for health systems and society. In England, the cost of health care for ulceration and amputation in diabetes during 2014-2015 was estimated at between £837 million and £962 million; and it represented $0.8 \%$ to $0.9 \%$ of the $\mathrm{Na}$ tional Health Service (NHS) budget (57). In Brazil, the direct medical costs related to DF ulceration was estimated at US $\$ 180$ million in 2014 (58). On the other hand, in Peru, the direct annual cost of prevention and management attributable to DF patients at high-risk ulceration was calculated at $\$ 74.5$ million in the sub-optimal care system in 2012 (59); however, the comparison of cost for this pathology between developing and developed countries is difficult to perform.

Also, the authors calculated the direct annual cost of prevention and management of DF patients in two different care systems: a standard care system according to the International Diabetes Federation (IDF), and an intensive strategy based on standard care plus temperature monitoring. Both were compared with the sub-optimal care system. The implementation of the first system in Peru decreases the cost-of-illness by $\$ 71.8$ million dollars with the prevention of 791 deaths. On the other hand, with the implementation of the second care system, the cost increases to $\$ 96.8$ million dollars, but 1,385 deaths can be halted.

These results show that the current sub-optimal care system is not cost-effective and death by diabetic foot can be preventable; however, this study has various limitations due to the lack of reliable information to estimate some costs as mobilization costs and waiting time, among others. In the light of the theoretical estimates, we suggest these results should be verified.

\section{LIMITATIONS OF PERUVIAN LITERATURE}

While the present review shows important studies to understand the impact of the DF on the Peruvian population and health system, certain limitations should be acknowledged regarding Peruvian literature in DF: a) poorly labelled studies may have been unintentionally omitted in the synthesis of the Peruvian literature, since some papers are not published in indexed journals in electronic databases. Greater investment in the appropriate indexing of Peruvian research in electronic databases is urgently required $(18,60)$. b) The majority of works are single-center studies and focus on population attended at hospitals of Lima (the capital city). This fact makes the extrapolation of the outcomes at national level difficult. c) Finally, most of the studies analyzed clinical charts of DF patients, provided data at only one point of time and, in some cases, worked with a small sample. Longitudinal and prospective studies are required to improve the level of evidence about this problem in Perú.

In general, the literature available in Latin America about DF is scarce and presents similar limitations to those present in the Peruvian studies $(14,17,61)$.

\section{CONCLUSIONS}

Although early identification of risk factors for DF is crucial for its epidemiological control, we have to face great challenges to improve diagnosis, management and treatment of these patients in Perú, to reduce the medical and economic burdens of this disease as it mainly becomes detrimental to patients from low-socioeconomic status. In addition, more national research should be conducted to better understand the real impact of DF on the Peruvian population. 


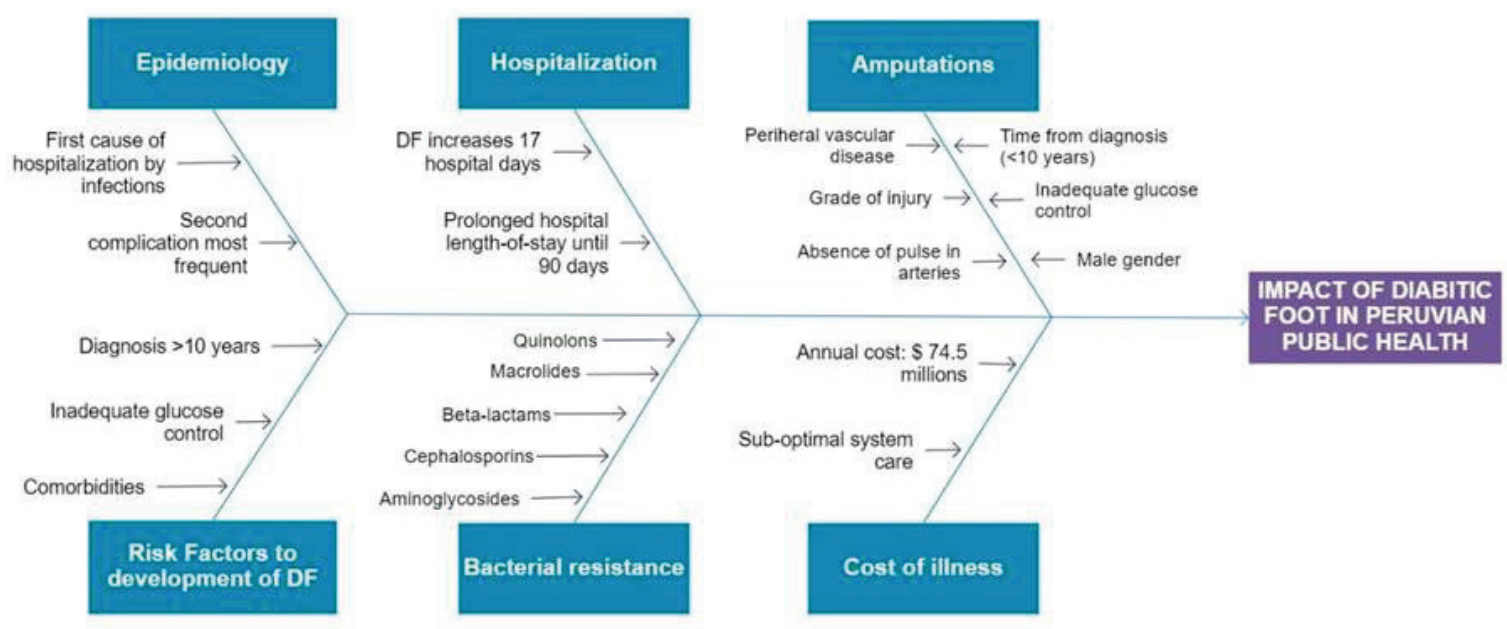

\section{ACKNOWLEDGEMENT}

The authors would like to thank the Universidad Privada San Juan Bautista for the economic funding ( $\mathrm{N}^{\circ} 032-2019$-VRI-UPSJB) to carry out this work.

\section{REFERENCES}

1. Saeedi P, Petersohn I, Salpea P, Malanda B, Karuranga S, Unwin N, Colagiuri S, Guariguata $\mathrm{L}$, Motala AA, Ogurtsova $\mathrm{K}$, Shaw JE, Bright D, Williams R. Global and regional diabetes prevalence estimates for 2019 and projections for 2030 and 2045: Results from the International Diabetes Federation Diabetes Atlas, 9th edition. Diabetes Res Clin Pract [Internet]. 2019;157:107843. Available from: https://doi.org/ 10.1016/j. diabres. 2019.107843

2. Boulton AJ, Vileikyte L, Ragnarson-Tennvall $\mathbf{G}$, Apelquist $\mathbf{J}$. The global burden of diabetic foot disease. Lancet 2005;366:17191724.

3. Edmonds M, Manu C, Vas P. The current burden of diabetic foot disease. J Clin Orthop Trauma 2021;17:88-93. Available from: https://www.sciencedirect.com/ science/article/pii/ S0976566221000837

4. Kerr M. Foot care for people with diabetes: the economic case for change supporting, improving, earing [Internet]. 2012. Available from: https://diabetes-resources- production.s3-eu-west-1.amazonaws.com/ diabetes-storage/migration/pdf/footearefor-people- with-diabetes.pdf

5. van Netten JJ, Bus SA, Apelqvist J, Lipsky BA, Hinchliffe RJ, Game F, Rayman G, Lazzarini PA, Forsythe RO, Peters EJG, Senneville É, Vas P, Monteiro-Soares M, Schaper NC. Definitions and criteria for diabetic foot disease. Diabetes Metab Res Rev 2020;36(S1):1-6.

6. Pitoceo D, Spanu T, Di Leo M, Vitiello R, Rizzi A, Tartaglione L, Fiori B, Caputo S, Tinelli G, Zaceardi F, Flex A, Galli M, Pontecorvi A, Sanguinetti M. Diabetic foot infections: a comprehensive overview. Eur Rev Med Pharmacol Sci 2019;23(2):26-37.

7. Khanolkar M, Bain S, Stephens J. The diabetic foot. QJM 2008;101(9):685-695.

8. American Diabetes Assocation. 11. Microvascular complications and foot care: Standards of medical care in diabetes-2021. Diabetes Care 2021;44:S151-167.

9. Lim JZM, Ng NSL, Thomas C. Prevention and treatment of diabetic foot ulcers. J R Soc Med 2017;110(3):104-109.

10. Singh N, Amstrong DG, Lipsky BA. Preventing foot ulcers in patients with diabetes JAMA 2005;293(2):217-228.

11. Asociación Latinoamericana de Diabetes. Guías ALAD sobre el Diagnóstico, Control y Tratamiento de la Diabetes Mellitus Tipo 2 con Medicina Basada en Evidencia Edición 2019 [Internet]. Revista de la Asociación Latinoamericana de Diabetes 2019. Avai- 
lable from: http://www.revistaalad.com/ guias/5600AX191_guias_alad_2019.pdf

12. Yovera-Aldana $M$, Sáenz-Bustamante $S$, Quispe-Landeo Y, Agüero-Zamora R, Salcedo J, Sarria C, Gonzales-Grandez N, Briceño-Alvarado M, Antezana-Román A, Manrique H, Armstrong DG. Nationwide prevalence and clinical characteristics of inpatient diabetic foot complications: A Peruvian multicenter study. Prim Care Diabetes [Internet]. 2021 Mar 11; Available from: https://doi.org/10.1016/ j.ped.2021.02.009

13. Grupo de Estudio de la OMS sobre Prevención y Protección de la Diabetes Mellitus (1992: Ginebra S\& WHO. Prevención de la Diabetes Mellitus: informe de un Grupo de Estudio de la OMS. Ginebra: Orǵanización Mundial de la Salud; 1994.

14. Carro G V, Saurral R, Sagüüz FS, Witman EL. Pie diabético en pacientes internados en hospitales de Latinoamérica. Medicina (B Aires) 2018;78(4):243-351.

15. Ramos W, López T, Revilla L, More L, Huamaní M, Pozo M. Resultados de la vigilancia epidemiológica de diabetes mellitus en hospitales notificantes del Perú, 2012. Rev Peru Med Exp Salud Pública 2014;3(1):9-15.

16. Lazo-Porras M, Bernabe-Ortiz A, TaypeRondan A, Gilman RH, Malaga G, Manrique H, Neyra L, Calderon J, Pinto M, Armstrong DG, Montori VM, Miranda JJ. Foot thermometry with mHeath-based supplementation to prevent diabetic foot ulcers: A randomized controlled trial. Wellcome Open Res 2020;5:23.

17. Zhang $P$, Lu J, Jing Y, Tang S, Zhu D, Bi Y. Global epidemiology of diabetic foot ulceration: a systematic review and meta-analysis. Ann Med 2017;49(2):106-116.

18. Coffey L, Mahon C, Gallagher P. Perceptions and experiences of diabetic foot ulceration and foot care in people with diabetes: A qualitative meta-synthesis. Int Wound J 2019;16(1):183-210.

19. Joint British Diabetes Societies - Inpatient Care. Admissions avoidance and diabetes: guidance for clinical commissioning groups and clinical teams [Internet]. 2013. Available from: http://www.diabetologistsabed.org.uk/JBDS/JBDS_IP_Admissions_ Avoidance_Diabetes.pdf
20. Aǵwu E, Dafiewhare EO, Ekanem PE. Possible Diabetic-Foot Complications in SubSaharan Africa. In: Din T, editor. Global Perspective on Diabetic Foot Ulcerations, [Internet]. 2011. Available from: http:// www.intechopen.com/books/global-perspective-on-diabetic-foot-ulcerations/possible-diabetic-foot-complications-in-sub-saharan-africa.

21. Villena J, Burga, J, Corigliano S, Valdivia J. Morbimortalidad por diabetes mellitus no insulino dependiente (DMNID) en el Hospital Nacional Cayetano Heredia, 19851995. Rev Médica del Perú 1996;64-68.

22. Gonzales-Grández NN, Rodríguez-Lay EG, Manrique-Hurtado H. Características clínicas y factores asociados a morbilidad intrahospitalaria en los pacientes con diabetes mellitus tipo 2. Rev Soc Peru Med Interna 2013;26(4):159-165.

23. Hicks CW, Selvarajah S, Mathioudakis N, Sherman RL, Hines KF, Black III JH, Abularrage CJ. Burden of infected diabetic foot ulcers on hospital admissions and costs. Ann Vase Surg 2016;33:149-158.

24. Kasiya MM, Mang'anda GD, Heyes S, Kachapila R, Kaduya L, Chilamba J, Goodson P, Chalulu K, Allain TJ. The challenge of diabetic foot care: Review of the literature and experience at Queen Elizabeth Central Hospital in Blantyre, Malawi. Malawi Med J 2017;29(2):218-223.

25. Barbosa Marques AD, Sales da Silva LM, Magalhães Moreira TM, Martins Torres RA. Asociação entre internação hospitalar por diabetes mellitus e amputação de pé diabético. Enfermería Glob 2018;17(3):238.

26. Arribasplata-Espinoza Y, Luna-Muñoz C. Factores de riesgo asociados a pie diabético en el Hospital Pnp Luis N. Saenz, Año 2017. Rev la Fac Med Humana 2019;19(2):75-81.

27. Torres-Apareana HL, Gutiérrez C, PajueloRamírez J, Pando-Álvarez R, Arbañil-Huamán H. Características clínicas y epidemiológicas de los pacientes hospitalizados por pie diabético en el Hospital Nacional Dos de Mayo entre 2006 y 2008, Lima-Perú. Rev Peru Epidemiol 2012;16(3):1-6.

28. Ibarra CT, Rocha $\mathbf{J}$ de J, Hernández R, Nieves RE, Leyva R. Prevalencia de neuropatía periférica en diabéticos tipo 2 en el 
primer nivel de atención. Rev Med Chile 2012;140(9):1126-1131.

29. Damas-Casani VA, Yovera-Aldana M, Seclén Santisteban S. Clasificación de pie en riesgo de ulceración según el Sistema IWGDF y factores asociados en pacientes con diabetes mellitus tipo 2 de un hospital peruano. Rev Medica Hered 2017;28(1):5.

30. Boulton AJ. The pathogenesis of diabetic foot problems: an overview. Diabet Med 1996;13 Suppl 1:S12-16.

31. Mañas LR, Bouzon CA, Rodríguez MC. Peripheral Arterial Disease in Old People with Diabetes. In: Diabetes in Old Age. John Wiley \& Sons, Ltd; 2009; 39-49.

32. Gómez-Hoyos E, Levy E, Díaz-Perez A, Cuesta-Hernández M, Montañez-Zorrilla C, Calle-Paseual AL. Pie Diabético. Semin la Fund Española Reum 2012;13(4):119-129.

33. Rodríguez-Alonso $\mathrm{D}$, Mercedes-Chávez $\mathrm{F}$, Rodríguez-Díaz D, Polo-López T, RiveraBegazo Á, Guzmán Yparraguirre EM. Prevalencia moderada de pie en riesgo de ulceración en diabéticos tipo 2 según IGWDF en el contexto de la atención primaria. Horiz Med (Barcelona) 2018;18(4):9-18.

34. Cardoso HC, Zara ALDSA, Rosa SDSRF, Rocha GA, Rocha JVC, Araújo MCE De, Quinzani PDF, Barbosa YP, Mrué F. Risk factors and diagnosis of diabetic foot ulceration in users of the Brazilian Public Health System. J Diabetes Res 2019;2019:5319892. doi: $10.1155 / 2019 / 5319892$

35. Bekele F, Chelkeba L, Fekadu G, Bekele K. Risk factors and outcomes of diabetic foot uleer among diabetes mellitus patients admitted to Nekemte referral hospital, western Ethiopia: Prospective observational study. Ann Med Surg 2020;51(January):17-23. Available from: https://doi.org/10.1016/ j.amsu.2020.01.005

36. Merza $Z$, Tesfaye $S$. The risk factors for diabetic foot ulceration. Foot 2003;13(3):125129.

37. Ghanassia E, Villon L, Dieudonné JFTD, Boegner C, Avignon A, Sultan A. Longterm outcome and disability of diabetic patients hospitalized for diabetic foot ulcers. Diabetes Care 2008;31(7):1288-1292.

38. Capellari C, Pinheiro da Costa-Bartira E, Larre A, Pasin D, Cardoso A, Vasconcelos L de, Figueiredo AE. Educational interven- tions and ǵlycemic control: Integrative Review. J Diabetes Metab 2016;7(6).

39. Lavery LA, Armstrong DG, Wunderlich RP, Mohler MJ, Wendel CS, Lipsky BA. Risk factors for foot infections in individuals with diabetes. Diabetes Care 2006;29(6):12881293.

40. MeInnes AD. Diabetic foot disease in the United Kingdom: About time to put feet first. J Foot Ankle Res 2012;5(1):1-7.

41. National Health Service. National Diabetes Foot Care Audit (NDFA) Hospital Admissions Report 2014-2017 [Internet]. 2017. Available from: https://files.digital.nhs.uk/ publication/ 0/d/ndfa_2014-2016_-_hospital_admissions_executive_report.pd $\bar{f}$

42. Mejia CR, Paucar-Tito LO, Morales-Concha L, Rondón-Abuhadba EA, AtamariAnahui N, Ordoñez-Linares ME. Association between hospitalization stay and diabetic foot: an analytical cross-sectional study in three Peruvian hospitals. Medwave 2018;18(07):e7336-e7336.

43. Tan JH, Hong CC, Shen L, Tay EYL, Lee JKX, Nather A. Costs of patients admitted for diabetic foot problems. Ann Acad Med Singapore 2015;44(12):567-570.

44. Game F, RJ H, Apelqvist J, Bakker K, Hatermann A, Löndahl M, Price P, Jeffeoate W. A systematic review of interventions to enhance the healing of chronic ulcers of the foot in diabetes. Diabetes Metab Res Rev 2012;28(suppl 1): 119-141. doi: 10.1002/ dmrr.2246.

45. Zelada H, Bernabe-Ortiz A, Manrique $H$. Inhospital mortality in patients with type 2 diabetes mellitus: A prospective cohort study in Lima, Peru. J Diabetes Res 2016;2016.

46. Yovera-Aldana M, Rodrígue A, Vargas M, Heredia P, Huamán M, Vargas-Vilea J, Yalán C, García-Orbegoso E. Resistencia bacteriana y factores asociados en pacientes con pie diabético infectado sin desenlace de amputación mayor en un hospital nacional peruano. Acta Médica Perú 2017;34(3):173-181.

47. Alcántara W, Flores R, Garmendia F. Prevalencia y riesgo de amputación en pacientes con pie diabético. An Fac Med (Perú) 1999;60(3):159-164.

48. Lipsky BA, Berendt AR, Cornia PB, Pile JC, Peters EJG, Armstrong DG, Deery HG, 
Embil JM, Joseph WS, Karchmer AW, Pinzur MS, Senneville E. 2012 infectious diseases society of America clinical practice guideline for the diagnosis and treatment of diabetic foot infections. Clin Infect Dis 2012;54(12):132-173.

49. Falcón FE, Villanueva JS, Arizmendiz LN. Estudio bacteriológico de pacientes con pie diabético infectado en el Hospital Arzobispo Loayza. Rev Soc Peru Med Interna 2006;19(1):5-9.

50. Neyra L, Lezama V, Lezama W, Medina M, Murillo F, Purizaga H, Válcarcel B. Bacteriología y resistencia bacteriana en el pie diabético infectado en el Hospital Nacional Arzobispo Loayza, Lima. Rev Soc Peru Med Interna 2017;30(1):24-27.

51. Johannesson A, Larsson GU, Ramstrand N, Turkiewicz A, Wiréhn AB, Atroshi I. Incidence of lower-limb amputation in the diabetic and nondiabetic general population: A 10-year population-based cohort study of initial unilateral and contralateral amputations and reamputations. Diabetes Care 2009;32(2):275-280.

52. Lepäntalo M, Apelqvist J, Setacei C, Riceo JB, De Donato G, Becker F, Robert-Ebadi H, Cao P, Eckstein HH, De Rango P, Diehm N, Schmidli J, Teraa M, Moll FL, Dick F, Davies AH. Chapter V: Diabetic foot. In: European Journal of Vascular and Endovascular Surgery 2011; 60-74.

53. Farro L, Tapia $R$, Bautista $L$, Montalvo $R$, Iriarte H. Características clínicas y demográficas del paciente amputado. Rev Medica Hered 2012;23(4):240.

54. Verrone Quilici MT, Del Fiol FDS, Franzin Vieira AE, Toledo MI. Risk factors for foot amputation in patients hospitalized for diabetic foot infection. J Diabetes Res 2016; 2016:8931508. doi: 10.1155/ 2016/8931508.
55. Vidal-Domínguez G. Factores de riesgo de amputación en el pie diabético. Rev Soc Peru Med Interna 2010;23(4):145.

56. Nicho-Alegre LF, Luna-Muñoz $C$, De La Cruz-Vargas JA. Factores de riesgo determinantes en la amputación de pacientes con pie diabético en el servicio de medicina del Hospital Luis N. Saenz en el período, enero 2015 - julio 2016. Rev Fac Med Humana $2017 ; 17(1): 72-78$.

57. Kerr M, Barron E, Chadwick P, Evans T, Kong WM, Rayman G, Sutton-Smith M, Todd G, Young B, Jeffeoate WJ. The cost of diabetic foot ulcers and amputations to the National Health Service in England. Diabet Med 2019;36(8):995-1002.

58. Toscano CM, Sugita TH, Rosa MQM, Pedrosa HC, Rosa R dos S, Bahia LR. Annual direct medical costs of diabetic foot disease in Brazil: A cost of illness study. Int J Environ Res Public Health 2018;15(1):1-13.

59. Cárdenas MK, Mirelman AJ, Galvin CJ, Lazo-Porras M, Pinto M, Miranda JJ, Gilman RH. The cost of illness attributable to diabetic foot and cost-effectiveness of secondary prevention in Peru. BMC Health Serv Res 2015;15(1):1-10.

60. Shaw RL, Booth A, Sutton AJ, Miller T, Smith JA, Young B, Jones DR, DixonWoods M. Finding qualitative research: An evaluation of search strategies. BMC Med Res Methodol 2004;4:1-5.

61. Sánchez-Cruz LY, Martínez-Villarreal AA, Lozano-Platonoff A, Cárdenas-Sánchez A, Contreras-Ruiz J. Epidemiología de las úlceras cutáneas en Latinoamérica. Med Cutan Ibero Lat Am 2016;44(3):183-197. 